\title{
Attitudes of preservice physical educators toward individuals with disabilities at University Parthenope of Napoli
}

\author{
Marco Di Nardo, ${ }^{1, *}$, Martin Kudláček ${ }^{2}$, Domenico Tafuri ${ }^{3}$, and Jana Sklenaříková ${ }^{2}$ \\ ${ }^{1}$ Faculty of Kinesiology and Rehabilitation Sciences, Catholic University, Leuven, Belgium; ${ }^{2}$ Faculty of Physical Culture, \\ Palacký University, Olomouc, Czech Republic; and ${ }^{3}$ University Parthenope, Napoli, Italy
}

Copyright: (C) 2014 M. Di Nardo et al. This is an open access article licensed under the Creative Commons Attribution License (http://creativecommons.org/licenses/by/4.0/).

\begin{abstract}
Background: Inclusion refers to the notion that all students, regardless of disability (mild or severe), will be taught in regular education classes even if special resources are needed. Attitudes about inclusion are extremely complex and vary from country to country and school to school. One of the factors influencing the effective implementation of inclusion is the teacher's attitudes. The latest results from literature show that attitudes toward people with disabilities are changing in a positive direction over the last few decades. Objective: The purpose of this study was to examine the effects of an undergraduate adapted physical education course on the attitudes of pre-service physical educators toward individuals with disabilities. Methods: The Attitudes Towards Individuals with Physical Disabilities in Physical Education (ATIPDPE) instrument, based upon the Theory of Planned Behaviour (Ajzen, 1991) was used to measure the attitudes of pre-service teachers within three groups of students of the Department of Sport Science at the Università Degli Studi di Napoli "Parthenope" (Italy) enrolled in the $1^{\text {st }}$ and $3^{\text {rd }}$ year of Bachelor's studies in the Department of Sport Science, and students enrolled in the last year of a Master degree in Motor Activities and Preventive for Health. The software package SPSS 19.0 was used to analyze results via a Mann-Whitney $U$ test and multiple regression analysis. Results: Although no significant differences between the groups were found in relation to group year or subject major, results found positive attitudes of pre-service teachers towards inclusion (Physical Education (PE) $1^{\text {st }}$ year attitude $($ ATT $)$ mean $=58.93 ;$ PE $3^{\text {rd }}$ year ATT mean $=61.11$; Postgraduate $2^{\text {nd }}$ year mean $\left.=59.80\right)$, as well as very high intentions. Attitudes were found to account for $30 \%$ of variance of intentions $\left(R^{2}=.30\right)$. Conclusion: This research concluded that it is necessary to further improve and develop attitudes and intentions of pre-service teachers to ensure the implementation of successful inclusive physical education programs. In order to achieve this, university courses need to provide more effective courses and experiences relating to the teaching of students with disabilities.
\end{abstract}

Keywords: inclusion, adapted physical education, behaviour, physical disability

\section{Introduction}

It is estimated that in Italy there are about 2,824,000 persons with disabilities. The number of persons with disabilities (of 6 years or more) living in a family is about $2,615,000$ units, this equals to $4.85 \%$ of the population (Livi Bacci, 1999). Disabled are mainly people aged 60 years and older - $17 \%$ of the persons with disabilities are 60 years old $(2,057,000)$ and $37.7 \%$ are 75 years old or older. There are 620,000 persons with disabilities under the age of 60 years, from which 188,000 are younger than 14 years.

\footnotetext{
* Address for correspondence: Marco Di Nardo, EMMAPA, Faculty of Kinesiology and Rehabilitation Sciences, KU Leuven, Tervuursevest 101, 3001 Leuven, Belgium. E-mail: marcodinardo08@gmail.com
}

Inclusion consists of educating all students, regardless of their ability or disability level, together in one educational environment, while meeting the needs of each of these individuals. In such cases, "the general physical education teacher will make all necessary changes in didactics, pedagogy and curriculum to assure that all students will achieve their physical education goals and feel safe, happy, comfortable, and successful in the physical education setting" (Kudláček, 2001, p. 190).

All students, regardless of disability, are educated in the integrated, general education class. Regular teachers are asked to provide experiences that are appropriate for all of their students. The special education teacher provides support in the regular classroom (Stainback $\&$ Stainback, 1992). The resource room is at least partially replaced with the special education teacher 
consulting from room to room. Inclusion in education is an approach to educating students with special educational needs. In today's education system, the number of school districts implementing inclusion for their students with disabilities has increased significantly during the last 25 years. Inclusion has been and continues to be a powerful force, in fact it is a set of attitudes that together provide a welcoming and supportive educational environment, one that is respectful and appreciative of individual differences, and one in which all students participate regardless of gender, motor ability or challenging condition (disability).

Inclusive education provides benefits for all students and school personnel and serves as an example for an inclusive society. It is believed that inclusion is advantageous for several reasons. It provides students with a more stimulating and motivating environment, inclusive practices help students with disabilities to be viewed as members of the class, to have more skilful role models and to participate in better age-appropriate activities (Block, 2000). The three autistic students in the Downing, Morrison, and Berecin-Rascon study (1996) all increased their level of participation and time on-task from the beginning of the year to the end. They were also found to spend more time with the class doing the same activities rather than parallel or separate activities. This is a significant outcome, as students' sense of belonging, self-esteem, and engagement are all affected by participating in the regular activities of the classroom alongside their peers (Schnorr, 1990). Another possible benefit of inclusion is that friendships will result from the classroom interactions and that these friendships will become future natural supports for the students into adulthood. When students with disabilities are in segregated classrooms, the number and types of friendships they can have are limited. However, just placing students within general education settings does not guarantee reciprocal social relationships. Research has found that without the proper support the benefits of social interactions and friendships are not ensured even in an inclusive classroom (Taylor, Peterson, McMurray-Schwarz, \& Guillou, 2002). According to Falvey (1995), friendships and relationships are extremely important to students with disabilities because they provide support and nurture the skills that they will need to be able to participate and work in their local communities. When included with the proper supports, students with disabilities of all severities gain more meaningful friendships (Vaughn, Elbaum, Schumm, \& Hughes, 1998). Attitudes constitute an important determinant of behaviour in educational settings. With this in mind, a sound theoretical foundation of attitude research is important so that educational practice such as inclusive physical education can be explained and controlled (Tripp \& Sherrill, 1991). Attitude can be defined as a positive or negative evaluation of people, objects, events, activities, ideas, or just about anything in your environment (Zimbardo \& Leippe, 1991). The attitude is, therefore, the dynamic element in human behaviour, the motive of activity. An attitude comprises of three parts (Breckler \& Wiggins, 1992): (a) the AFFECTIVE component is the emotional (like/dislike) component of an attitude; (b) the BEHAVIORAL component is the overt behaviour attached to our internal attitudes; (c) the COGNITIVE component is the storage component, where we organize information about an attitude object. Attitudes can be oriented towards anything ranging from, for example - objects, oneself, other persons, a disability, or a racial group (McMurray, 2003).

The theory of planned behavior (TPB) postulates three conceptually independent determinants of intention. In the TPB, the concept of perceived behavioural control is comprised of control beliefs and a perceived power associated with those beliefs (Ajzen, 1991). Control beliefs are influenced by previous experience with the behaviour, other information about the behaviour, and other factors that influence the perceived difficulty of performing certain behaviour. For example, perceived behavioural control regarding teaching inclusive physical education may be influenced by the effectiveness of pre-service preparation (e.g. competency in individualizing instructions, familiarity with using peer tutor strategies), the extent and quality of personal experience with inclusive physical education, type and amount of personnel support (e.g. adapted physical educator, paraprofessionals, volunteers), class size, and type and severity of disability. Each factor may play a different role for different individuals. As such, when applying the TPB, it is believed that teachers will have more favourable intentions towards teaching students with disabilities when they possess more favourable accessible beliefs, attitude, subjective norm and perceived control about teaching these students (Fournidou, Kudláček, \& Evagellinou, 2011; Tripp \& Rizzo, 2006). Therefore by changing the three predictors; attitude toward behaviours, subjective norm and perceived behavioural control, it is possible to increase the intention of an individual to carry out a desired behaviour (Doulkeridou, Evagellinou, \& Kudláček, 2010).

In many countries, a continuous change toward more inclusive educational settings for children with disabilities is being observed (DePauw \& Doll-Tepper, 2000; Lienert, Sherrill, \& Myers, 2001). Including students with disabilities in general physical education by physical educators in a safe, successful, and satisfying way requires adaptations in planning, implementation, 
and evaluation. Academic preparation, assuming that adapted physical educators have had more academic preparation concerning teaching individuals with disabilities than general physical educators do. Further questioning the effects of (adapted) physical education academic preparation on attitudes, Folsom-Meek, Nearing, Groteluschen, and Krampf (1999) and Schmidt-Gotz, Doll-Tepper, and Lienert (1994) found that students with majors other than physical education (e.g. special education, elementary education) displayed more positive attitudes than physical education majors did. However, Kudláček, Válková, Sherrill, Myers, and French (2002) reported that students majoring in adapted physical education had more favourable attitudes than students majoring in general physical education did. These findings are inconclusive at best and indicate a need to examine pre-service and in-service preparation of the physical education teachers. The purpose of the presented study was to examine the effects of an undergraduate adapted physical education course on the attitudes of pre-service physical educators toward individuals with disabilities.

\section{Methods}

Ethical approval for this research was granted by the Faculty of Sport Sciences, University of Naples, Italy.

\section{Participants}

The data collection was completed during the examination period in February-March 2012. Participants were 125 undergraduate physical education students enrolled in the first year study of a Bachelor of Physical Education (47 females and 78 males) of an average age of 20.11 years. 98 participants (50 females and 48 males) of an average age of 23.35 years were enrolled in the third year study of Bachelor of Physical Education. Participants (30 females and 35 males) of an average age of 26.05 years were enrolled in the last year of postgraduate education in Sport Sciences for the prevention and wellness Master. Each of these courses was realized at the Faculty of Sport Sciences, University of Naples, Italy.

The goal was to obtain as many participants as possible within the three mentioned courses. The sampling design was purposive; therefore all students, who met the criteria of (a) enrolment in the pre-service programs mentioned above, (b) willingness of the course instructor to allocate time and space during the period of examinations for the survey, and (c) the willingness of students to participate in the study were surveyed (Table 1).
Table 1

Participants in the studies, $n$ (mean age in years)

\begin{tabular}{lccc}
\hline Participants & Males & Females & $\begin{array}{c}\text { Combined } \\
\text { total }\end{array}$ \\
\hline $1^{\text {st }}$ year of Bachelor & 78 & 47 & 125 \\
& $(19.8)$ & $(19.8)$ & $(20.12)$ \\
$3^{\text {rd }}$ year of Bachelor & 48 & 50 & 98 \\
& $(23.7)$ & $(22.9)$ & $(23.34)$ \\
$2^{\text {nd }}$ year of Postgraduate & 35 & 30 & 65 \\
& $(26.0)$ & $(26.1)$ & $(26.04)$ \\
Combined total & 161 & 127 & 288 \\
& $(22.3)$ & $(22.8)$ & $(22.55)$ \\
\hline
\end{tabular}

\section{Instrument}

The Italian version of "Attitudes Toward Teaching Individuals with Physical Disabilities in Physical Education" (ATIPDPE) was used for this study. In this study the instrument was used to measure the attitudes of pre-service Italian physical educator's students towards inclusion of students with physical disabilities in general physical education classes. The original ATIPDPE was developed by Kudláček, Válkova, Sherrill, Myers, and French (2002) in the Czech language.

To use the ATIPDPE questionnaire it was necessary to translate it from English to Italian. The translation of this questionnaire was made by back-translation technique and requires four bilingual translators (Banville, Desrosiers, \& Genet-Volet, 2000). In this study, the four translators (A - the main researcher, B, C, D) were bilingual for the students. First, two translators (A and $\mathrm{B}$ ) translated the original version into the Italian language. Having two persons doing the translation in parallel avoids possible bias of one person. The instruction given to the translators was that the literal translation is neither essential nor desired. They should look for the meaning of the statement rather than the word-for-word translation. When translators A and B finished, they compared their versions. The Italian version was given to two other bilingual persons in the field of physical education ( $C$ and $D$ ), who retranslated the instrument back into English. Neither C nor D knew the original version. Finally the translations were compared. The questionnaire starts with the purpose of the survey, general instructions for correct completion of the questionnaire and an example of using the rating scale, while answering an item. Part I and II of the survey are composed of items relating to the level of understanding of the definitions. Part I consists of the definition of students with physical disabilities (PD). Part II consists of definitions of inclusion. Part III is the main part of the questionnaire, which is constructed to include items relating to intention 
statements (4), behavioural beliefs (12), normative beliefs (7) and control beliefs (8). All items in the survey use 7-point Liker scale, 1 being the lowest and 7 the highest. The three components of TBP that are posited to predict intention in the ATIPDPE questionnaire are the attitude toward behaviour, subjective norm and perceived behavioural control. In addition, the ATIPDPE instrument measures three psychological components: a) positive outcome for students, b) negative outcome for students, and c) negative outcome for teachers.

In addition, the ATIPDPE instrument was measured by two psychological components - positive outcome for students and negative outcome for students.

Enclosed with the questionnaire was a participant information sheet providing personal information as well as information related to the previous adapted physical activity experience.

\section{Scoring}

The questionnaire was distributed and collected by the schools' principle to an equal distribution according to the percentage of education students enrolled in Sport Sciences. To achieve non-biased and more honest responses, all completed questionnaires were anonymous. We made necessary modifications to the questionnaire in the scoring part, to make the text comprehension easier for students and avoid annoying the participants. According with Rizzo (1993, Physical Educators' Attitude Toward Teaching Individuals with Disabilities - PEATID-III), the scoring system requires the use of two 7-point scales, but we decided to use only one unipolar evaluative scale (Aizen, 2008 Scaling and testing multiplicative combinations in the expectancy - value model of attitudes) such as 7-point scale that ranges from "strongly agree" and "strongly disagree", as seen in Table 2, instead of two 7-point scales without using the likelihood construct for assessment of behavioural beliefs. We could use these ratings because the valence of the outcome (positive and negative) was clearly established as the positive as well as the negative outcome were judged as important. The results were then collated and subsequently referred to as the summative belief index or attitudinal score. Specifically, behavioural belief evaluation scores, normative belief strength scores, and control belief power scores will be transformed in a unipolar scale $(1,2,3$, $4,5,6,7)$.

\section{Data analysis}

To compare the attitudes between the groups of preservice physical educators from Italy, in relation to year level and subject major, a Mann-Whitney $U$ test was used. Software package SPSS PC 19.0 (the level of significance was set at .05) was used to determine if there were any significant differences between students in relation to their attitudes, subjective norm, perceived behavioural control and intention to include students with physical disabilities in general physical education classes.

\section{Results}

The sample of students from Faculty of Sport Sciences, University of Naples, Italy; consisted of 288 undergraduate physical education students from the following courses; first year Bachelor of Physical Education $(n=125)$, third year study of Bachelor of Physical Education $(n=98)$, second year of postgraduate education in Sport Sciences for the prevention and wellness Master $(n=65)$. Results from the demographic data study (Table 3 ) found that there were majority of male participants $(n=161)$ compared to female participants $(n=127)$ in the study. Only in the $3^{\text {rd }}$ year of Bachelor's the number of female participants $(n=50)$ was higher than the number of the male participants $(n=48)$. Approximately $64.3 \%$ of participants enrolled in the first and third year Bachelor of Physical Education and in the second year of postgraduate had some personal experience with people with physical disabilities. Only 7 students from the combined participants found this experience to be not good, while $24.4 \%$

Table 2

Sample items from the attitudinal scale

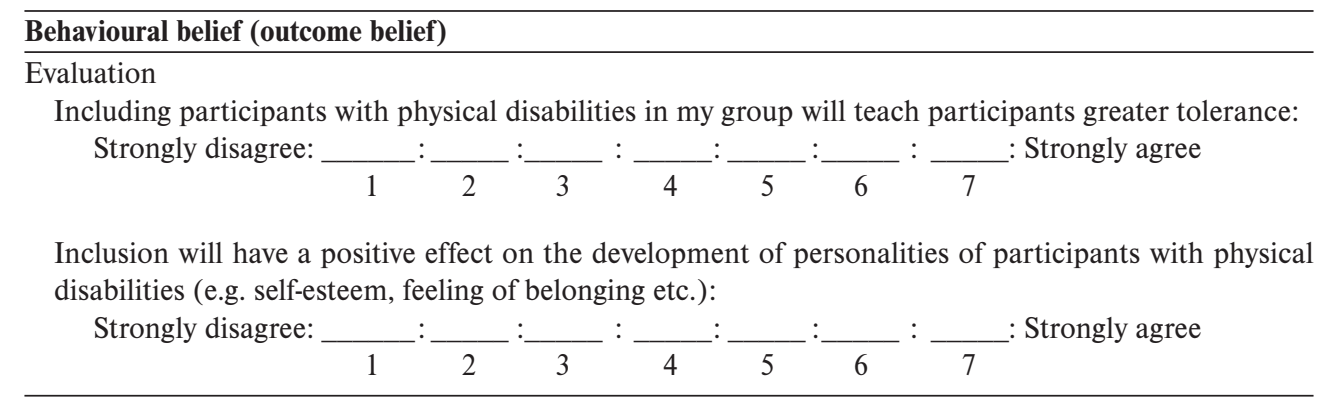


Table 3

Demographic data: $1^{\text {st }}$ and $3^{\text {rd }}$ year of Bachelor, $2^{\text {nd }}$ year of Postgraduate

\begin{tabular}{|c|c|c|c|}
\hline Variable & $\begin{array}{c}1^{\text {st }} \text { year of Bachelor } \\
(\%)\end{array}$ & $\begin{array}{c}3^{\text {rd }} \text { year of Bachelor } \\
(\%)\end{array}$ & $\begin{array}{c}2^{\text {nd }} \text { year of Postgraduate } \\
(\%)\end{array}$ \\
\hline Females, \% (n) & $37.6(47)$ & $51.1(50)$ & $46.2(30)$ \\
\hline Males, \% ( $n)$ & $62.4(78)$ & $48.9(48)$ & $53.8(35)$ \\
\hline Personal experience with people with PD & 59.2 & 64.3 & 69.2 \\
\hline \multicolumn{4}{|l|}{ Evaluation of experience with $\mathrm{PD}^{\mathrm{a}}$ : } \\
\hline not good & 0.8 & 2.0 & 6.2 \\
\hline satisfactory & 24.4 & 31.6 & 30.8 \\
\hline very good & 21.6 & 21.4 & 27.7 \\
\hline outstanding & 14.4 & 9.2 & 4.6 \\
\hline Completion of a university APA course & 23.2 & 41.8 & 67.7 \\
\hline $\begin{array}{l}\text { Provided with information on PD and PE } \\
\text { outside of university }\end{array}$ & 49.6 & 40.2 & 55.1 \\
\hline \multicolumn{4}{|l|}{$\begin{array}{l}\text { Perceived competence to teach partici- } \\
\text { pants with PD today: }\end{array}$} \\
\hline not at all & 16.6 & 25.5 & 15.4 \\
\hline somewhat & 51.2 & 61.2 & 60.0 \\
\hline very & 32.8 & 13.3 & 24.6 \\
\hline \multicolumn{4}{|l|}{$\begin{array}{l}\text { Perceived competence to teach partici- } \\
\text { pants with PD after graduation: }\end{array}$} \\
\hline not at all & 17.6 & 22.4 & 23.1 \\
\hline somewhat & 48.0 & 50.0 & 38.5 \\
\hline very & 34.4 & 27.6 & 38.5 \\
\hline Intention to teach PE after graduation & 80.0 & 74.5 & 72.3 \\
\hline
\end{tabular}

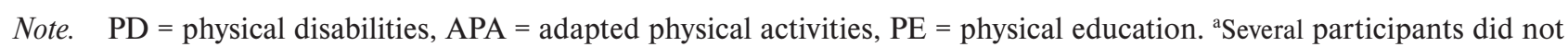
complete this question if they had no experience with people with PD.

and $31.6 \%$ and $30.8 \%$ of students from the first and third year of Bachelor and second postgraduate respectively found their experiences to be satisfactory, $21.6 \%$, $21.4 \%$ and $27.7 \%$ informed of very good experiences and $14.4 \%, 9.2 \%$ and only $4.6 \%$ respectively noted that their experience with persons with physical disabilities was outstanding. There was considerable difference among the number of students who had completed a course at university relating to adapted physical activity (APA). While only $23.2 \%$ of the first year Bachelor students had completed such a course, $41.8 \%$ within the third year Bachelor participants had completed a related course, and $67.7 \%$ of the second year of postgraduate had completed a related course. It was also respectively reported that $49.6 \%$ of the first year of Bachelor and $40.2 \%$ of the third year of Bachelor students and only $55.1 \%$ of second year of postgraduate had received more forms of information related to physical education and sport for individuals with physical disabilities outside of their university studies. When asked, how competent the pre-service participants felt at the current time to teach physical education to students with physical disabilities, the first year of Bachelor students replied with $16.6 \%$ indicating not at all, $51.2 \%$ indicating somewhat, and only $32.8 \%$ indicating that they felt very prepared. Of the third year Bachelor, $25.5 \%$ felt not at all competent, $61.2 \%$ felt somewhat competent, and only $13.3 \%$ felt very competent. For the second year of Postgraduate $15.4 \%$ indicated not at all, $60.0 \%$ indicating somewhat and $24.6 \%$ felt very competent. Responses didn't vary as much when asked about their perceived competence to teach students with PD after graduation. The first and third year of Bachelors respectively, $17.6 \%$ and $22.4 \%$ and $23.1 \%$ of the second year of postgraduate students replied that they would feel not at all competent, $48.0 \%$ and $50.0 \%$ and $38.5 \%$ replied that they would feel somewhat competent, while $34.4 \%$ and $27.6 \%$ and $38.5 \%$ replied that they would feel very competent to teach students with physical disabilities in physical education after completing their teacher preparation course. $80.0 \%$ of respondents from the first year of Bachelors, $74.5 \%$ and $72.3 \%$ of 
respondents from others two classes, replied that they intend to teach after graduation. It is important to note that preliminary analysis was performed on participants who had and also had not completed an adapted physical activity course in the university. Results were insignificant and hence this variable was not examined further.

In relation to overall attitudes towards teaching students with physical disabilities in physical education, the data shows that when comparing attitudes of the first year of students enrolled Bachelor and the second year of students enrolled at Postgraduate, there were no significant differences between the groups in relation to attitude, and also no significant differences between the groups in relation to intention (Table 4).

When comparing attitudes between male and female students, female students displayed slightly more positive attitudes towards teaching students with physical disabilities and also in regards to intention, female students displayed slightly more positive results (Table 5).

When comparing attitudes of the first and the third year students enrolled Bachelor, the third year students displayed slightly more positive attitudes towards teaching students with physical disabilities in physical education. While there were slightly more positive differences between the groups were in relation to intention (Table 6).

\section{Comparison of groups and descriptive statistics for the behavioral belief component}

No significant differences between overall attitudes in the first and the third year of Bachelor and the second year Postgraduate students were found during this study (Table 6 and 8). In order to investigate the foundation of participant attitudes in more detail, a Mann-Whitney $U$ test was performed on the responses of each of the twelve behavioral belief items within the ATIPDPE instrument. The scores on behavioral beliefs can be found in Table 7 .

Intention toward behaviour can be inferred from the summative behavioral belief index. Scores relating to the evaluation used 1 to 7 scales, while scores related to evaluation of a positive or negative outcome 1 to 7 , as explained previously in the Scoring chapter. When looking at the positive outcomes for students, results showed that all groups expressed that including students with physical disabilities in physical education (PE) will help other students to interact with and increase knowledge about people with disabilities as well as encouraging students to learn to help others, cooperation, to foster the learning of greater tolerance,

Table 4

Attitudes towards inclusion of $1^{\text {st }}$ year of Bachelor and $2^{\text {nd }}$ year of Postgraduate students

\begin{tabular}{lcccc}
\hline & $\begin{array}{c}1^{\text {st }} \text { year of Bachelor } \\
\text { Mean }(S D)\end{array}$ & $\begin{array}{c}2^{\text {nd }} \text { year of Postgraduate } \\
\text { Mean }(S D)\end{array}$ & $Z$ & $p$ \\
\hline Attitudes (ATT) & $58.93(8.16)$ & $59.80(8.17)$ & -0.83 & .41 \\
Intention (INT) & $22.98(5.36)$ & $25.14(3.95)$ & -0.80 & .42 \\
\hline
\end{tabular}

Table 5

Attitudes towards inclusion between male and female participants

\begin{tabular}{llcccc}
\hline & Group & $n$ & Mean $(S D)$ & $Z$ & $p$ \\
\hline Intention (INT) & Male & 161 & $24.27(4.48)$ & -2.31 & .02 \\
& Female & 127 & $25.13(3.95)$ & & \\
Attitudes (ATT) & Male & 161 & $59.63(8.69)$ & -0.61 & .54 \\
& Female & 127 & $60.36(8.66)$ & & \\
\hline
\end{tabular}

Table 6

Attitudes towards inclusion of $1^{\text {st }}$ and $3^{\text {rd }}$ year of Bachelor

\begin{tabular}{lcccc}
\hline & PE students $1^{\text {st }}$ year & PE students $3^{\text {rd }}$ year & & \\
& Mean $(S D)$ & Mean $(S D)$ & $Z$ & $p$ \\
\hline \multirow{2}{*}{ Attitudes (ATT) } & 58.93 & 61.11 & -1.31 & .90 \\
& $(8.16)$ & $(10.07)$ & & \\
Intention (INT) & 22.98 & 24.88 & -1.19 & .23 \\
\hline
\end{tabular}


Table 7

Means (SDs) of behavioural belief scores including individual belief items

\begin{tabular}{|c|c|c|c|}
\hline Benefits about the outcome & $\begin{array}{l}1^{\text {st }} \text { year PE students } \\
\quad(n=125)\end{array}$ & $\begin{array}{l}3^{\text {rd }} \text { year PE students } \\
\quad(n=96)\end{array}$ & $\begin{array}{l}2^{\text {nd }} \text { year PO students } \\
\qquad(n=65)\end{array}$ \\
\hline \multicolumn{4}{|l|}{ Positive outcomes for students } \\
\hline $\begin{array}{l}\text { 1) Including students with physical disabilities in my } \\
\text { PE classes will help students without disabilities to } \\
\text { learn to interact with person with physical disabilities }\end{array}$ & $\begin{array}{c}5.96 \\
(1.316)\end{array}$ & $\begin{array}{c}6.50 \\
(1.135)\end{array}$ & $\begin{array}{c}5.90 \\
(1.411)\end{array}$ \\
\hline $\begin{array}{l}\text { 3) Including students with physical disabilities in my } \\
\text { PE class will teach students to learn to help others }\end{array}$ & $\begin{array}{c}5.75 \\
(1.341)\end{array}$ & $\begin{array}{c}5.72 \\
(1.412)\end{array}$ & $\begin{array}{c}5.89 \\
(1.324)\end{array}$ \\
\hline $\begin{array}{l}\text { 5) Including students with physical disabilities in my } \\
\text { PE class will teach students greater tolerance }\end{array}$ & $\begin{array}{c}5.70 \\
(1.436)\end{array}$ & $\begin{array}{c}5.71 \\
(1.414)\end{array}$ & $\begin{array}{c}6.01 \\
(1.430)\end{array}$ \\
\hline $\begin{array}{l}\text { 6) Inclusion will have a positive effect on the devel- } \\
\text { opment of personalities of students with physical } \\
\text { disabilities (e.g. self-esteem, feeling of belonging etc.) }\end{array}$ & $\begin{array}{c}5.89 \\
(1.300)\end{array}$ & $\begin{array}{c}6.11 \\
(1.338)\end{array}$ & $\begin{array}{l}6.06 \\
(1.321)\end{array}$ \\
\hline $\begin{array}{l}\text { 9) Inclusion will cause my students to have better } \\
\text { knowledge about person with disabilities }\end{array}$ & $\begin{array}{c}5.33 \\
(1.879)\end{array}$ & $\begin{array}{c}5.56 \\
(1.506)\end{array}$ & $\begin{array}{c}5.70 \\
(1.548)\end{array}$ \\
\hline $\begin{array}{l}\text { 10) Including students with physical disabilities in } \\
\text { my PE class will teach students cooperation }\end{array}$ & $\begin{array}{c}6.24 \\
(0.980)\end{array}$ & $\begin{array}{c}6.12 \\
(1.408)\end{array}$ & $\begin{array}{l}6.10 \\
(1.370)\end{array}$ \\
\hline \multicolumn{4}{|l|}{ Negative outcomes for students } \\
\hline $\begin{array}{l}\text { 7) Students with physical disabilities will experience } \\
\text { discrimination in my group }\end{array}$ & $\begin{array}{c}6.01 \\
(1.694)\end{array}$ & $\begin{array}{c}5.32 \\
(2.034)\end{array}$ & $\begin{array}{c}5.50 \\
(2.031)\end{array}$ \\
\hline $\begin{array}{l}\text { 8) Students with physical disabilities will slow down } \\
\text { instruction and progress in my group }\end{array}$ & $\begin{array}{c}4.71 \\
(1.835)\end{array}$ & $\begin{array}{c}4.68 \\
(1.842)\end{array}$ & $\begin{array}{c}4.24 \\
(2.121)\end{array}$ \\
\hline $\begin{array}{l}\text { 11) Students without physical disabilities will experi- } \\
\text { ence discrimination in group }\end{array}$ & $\begin{array}{c}3.80 \\
(2.401)\end{array}$ & $\begin{array}{c}3.20 \\
(2.215)\end{array}$ & $\begin{array}{c}3.23 \\
(2.227)\end{array}$ \\
\hline $\begin{array}{l}\text { 12) Including students with physical disabilities in } \\
\text { my PE class will reduce the quality of lesson }\end{array}$ & $\begin{array}{c}5.65 \\
(1.606)\end{array}$ & $\begin{array}{c}5.07 \\
(2.072)\end{array}$ & $\begin{array}{c}4.67 \\
(2.129)\end{array}$ \\
\hline \multicolumn{4}{|l|}{ Negative outcomes for teaching } \\
\hline $\begin{array}{l}\text { 2) Including participations with physical disabilities } \\
\text { in my group will make teaching physical education } \\
\text { more difficult }\end{array}$ & $\begin{array}{c}3.28 \\
(1.516)\end{array}$ & $\begin{array}{c}3.12 \\
(1.789)\end{array}$ & $\begin{array}{c}3.30 \\
(1.767)\end{array}$ \\
\hline $\begin{array}{l}\text { 4) Including students with physical disabilities in } \\
\text { my group will make lesson planning and preparation } \\
\text { much more difficult }\end{array}$ & $\begin{array}{c}2.45 \\
(1.388)\end{array}$ & $\begin{array}{c}2.71 \\
(1.618)\end{array}$ & $\begin{array}{c}2.44 \\
(1.425)\end{array}$ \\
\hline \multicolumn{4}{|l|}{ Subjective norm beliefs } \\
\hline $\begin{array}{l}\text { 1) Most people, who are important to me think I } \\
\text { should not include participants with PD to my group }\end{array}$ & $\begin{array}{c}2.00 \\
(1.428)\end{array}$ & $\begin{array}{c}2.45 \\
(1.938)\end{array}$ & $\begin{array}{c}2.73 \\
(2.123)\end{array}$ \\
\hline $\begin{array}{l}\text { 2) People, whose decisions I respect, think I should } \\
\text { or should not include participants with PD to my } \\
\text { group. }\end{array}$ & $\begin{array}{c}2.36 \\
(1.705)\end{array}$ & $\begin{array}{c}2.54 \\
(1.927)\end{array}$ & $\begin{array}{c}2.55 \\
(1.968)\end{array}$ \\
\hline \multicolumn{4}{|l|}{ Control beliefs } \\
\hline $\begin{array}{l}\text { 1) To include participants with PD to my groups } \\
\text { would be for me very difficult or very easy. }\end{array}$ & $\begin{array}{c}4.67 \\
(1.389)\end{array}$ & $\begin{array}{c}4.36 \\
(1.737)\end{array}$ & $\begin{array}{c}4.58 \\
(1.477)\end{array}$ \\
\hline $\begin{array}{l}\text { 2) If I wanted I would be able to include participants } \\
\text { with PD to my groups }\end{array}$ & $\begin{array}{c}5.09 \\
(1.811)\end{array}$ & $\begin{array}{c}5.62 \\
(1.423)\end{array}$ & $\begin{array}{c}5.64 \\
(1.407)\end{array}$ \\
\hline
\end{tabular}

Note. $\mathrm{PE}=$ physical education, $\mathrm{PO}=$ postgraduate, $\mathrm{PD}=$ physical disability.

while developing the personalities of students with physical disabilities. Results demonstrated that the response of "strongly agree" of this occurring in the participant classes is quite high, as is their evaluation of this as a positive outcome of inclusive education. When considering belief items relating to negative outcomes for students, it can be noted that while the evaluation of events such as students experiencing discrimination in PE group, as well as students with PD slowing down PE group and reducing the quality of the PE class, data shows that the physical education students enrolled in the first and the third year of Bachelor did not seem to 
Table 8

Prediction of intention using multiple regression analysis

\begin{tabular}{|c|c|c|c|c|}
\hline Step & Variability & $R$ & $R^{2}$ & $\sigma_{\text {est }}$ \\
\hline 1 & Outcome belief 1 & .37 & .14 & 3.98 \\
\hline 2 & $\begin{array}{l}\text { Outcome belief } 1 \\
\text { Outcome belief } 6\end{array}$ & .46 & .21 & 3.81 \\
\hline 3 & $\begin{array}{l}\text { Outcome belief } 1 \\
\text { Outcome belief } 6 \\
\text { Outcome belief } 10\end{array}$ & .49 & .24 & 3.74 \\
\hline 4 & $\begin{array}{l}\text { Outcome belief } 1 \\
\text { Outcome belief } 6 \\
\text { Outcome belief } 10 \\
\text { Outcome belief } 4\end{array}$ & .51 & .26 & 3.69 \\
\hline 5 & $\begin{array}{l}\text { Outcome belief } 1 \\
\text { Outcome belief } 6 \\
\text { Outcome belief } 10 \\
\text { Outcome belief } 4 \\
\text { Outcome belief } 7\end{array}$ & .54 & .29 & 3.64 \\
\hline 6 & $\begin{array}{l}\text { Outcome belief } 1 \\
\text { Outcome belief } 6 \\
\text { Outcome belief } 10 \\
\text { Outcome belief } 4 \\
\text { Outcome belief } 7 \\
\text { Control belief } 2\end{array}$ & .55 & .30 & 3.61 \\
\hline
\end{tabular}

Note. $\sigma_{\text {est }}=$ standard error of the estimate is a measure of the accuracy of prediction. Details of outcome beliefs can be found in table 7.

display either high or low evaluation of this happening, meanwhile this was slightly different for students enrolled in the last year of postgraduate education in Sport Sciences for the prevention and wellness Master. However they did express that these outcomes were not desirable. The most negative outcome being that both students with and without physical disabilities would experience discrimination in the participant's PE group. There were not found significant differences between the two groups within the negative outcomes for teaching area, relating to a lesson preparation and teaching becoming more difficult if students with physical disabilities are to be included in the general physical education class, considering both the evaluation and belief index.

When considering the subjective norm beliefs, in the question: Most people, who are important to me think I should or should not include participants with PD to my group, we may notice a slight difference between education students enrolled in the first and third year of Bachelor and in students enrolled in the last year of postgraduate education in Sport Sciences for the prevention and wellness Master. Where students from the first year had a lower result compared with the other two groups.
While looking at control beliefs part, when asked: If I wanted, I would be able to include participants with PD to my groups, there was noticed a difference between education students enrolled in the first and third year of Bachelor and students enrolled in the last year of postgraduate education in Sport Sciences for the prevention and wellness Master. Students from the first year felt less able to include participants with PD into group compared with the other two groups. In order to predict the intention of participants to include students with physical disabilities into general physical education classes, a multiple regression analysis was performed. Results found, that outcome belief (subjective norm beliefs and control beliefs) are statistical predictors of the intention. Outcome belief $(1,6,10,4,7$, 2) was found to be the strongest predictor of intention with $30 \%\left(R^{2}=.30\right)$.

\section{Discussion}

Studies found that physical educators, who had received academic preparation as well as practical experiences related to people with disabilities, showed more positive intentions towards teaching students with disabilities in general physical education than those, who did not receive such education or practical experience (Tripp \& Rizzo, 2006). We found that participants with more education held positive attitudes towards including students with physical disabilities into general physical education classes. The intention toward inclusion was also increased with more education was found to be very high. Thus suggesting that pre-service teachers demonstrate high intentions to include students with physical disabilities in their physical education programs and confidence in regards to conforming to the social expectations to perform such behaviour. One aim of this study was to compare the attitudes of participants by year level. No significant differences were found. It is interesting to note that when looking at results, the PE third year students (mean $=61.11)$ held slightly higher attitude than the PE first year students $($ mean $=58.93)$ and postgraduate second year students $($ mean $=59.80)$. Although this is not a significant difference, possibly this result is justified by a greater amount of practical experience in schools, greater preparation and confidence, for both classes of students with higher results, it could be hypothesized that students enrolled in the third year of PE held slightly higher attitudes than the other two classes, because all students enrolled on the third year of study had to choose some additional course for collection of all mandatory credits. Demographic results showed that the second year postgraduate education 
students had a higher rate of completion of a university course related to students with disabilities than first year students. They also had increased practical experience in schools and overall competence to teach participants with PD after the graduation. While about perceived competence to teacher participants with PD today, first year pre-service PE students had higher results, the suggested reason might be that the first year students are more optimistic about the possibilities of teaching, while the second year postgraduate students are more realistic and have experienced the challenges of teaching.

Literature emphasizes the importance of academic preparation relating to people with disabilities and school programs, in the form of lectures, discussions, viewing successful inclusion programs, interaction and participation with students with disabilities in order to acquire understanding, meaningful, positive and practical experiences and hence develop more positive attitudes towards inclusion of students with physical disabilities in general educational settings (Tripp \& Rizzo, 2006), unfortunately due to insignificant results during preliminary analysis of data comparing students who had and had not completed a course related to students with disabilities at university, no significant differences were recorded. It was assumed that the more contact pre-service teachers have with persons with disabilities, the more positive attitudes they would have towards them. However the results of the current study did not support this hypothesis, where it was found that the amount of contact did not affect teacher's attitudes towards persons with disabilities. These results were not consistent with the findings of other studies (Leyser, Kapperman, \& Keller, 1994). The reason that contact did not affect pre-service teacher's attitudes could be the fact that their contact was random and was not for educational purposes. Only the postgraduate students had received information on physical disabilities outside of the university and had completed a university APA course. While Avramidis, Bayliss, and Burden (2000) found that there were slightly more positive attitudes towards inclusion from female pre-service teachers compared to males, this finding was also supported by Meegan and MacPhail (2006), who found that female teachers in Ireland held more positive attitudes than did male educators in relation to teaching students with special educational need. In the current study the difference between male and female was not statistically important, female participants displayed slightly more positive attitudes towards teaching students with physical disabilities.

In relation to predicting intentions of participants to perform certain behaviour, in this case to include students with physical disabilities in physical education programs, attitudes were found to be the strongest predictor with $30 \%$ predictability. Much literature lends support to the notion that it is possible to predict behaviour of individuals from their attitudes towards performing such behaviour and that behaviour specific attitudes have been shown to correlate well with the corresponding behaviour (Ajzen, 2005). The current research provides evidence that attitude towards performing such a behaviour has a $30 \%$ correlation towards the intention to carry out this behaviour, and hence this provides some support to the notion mentioned above that by measuring attitudes, it is possible to somewhat predict the intention of an individual to perform a certain behaviour. When comparing this with other literature whose results explain from 17 to $69 \%$ of variance (Sheeran \& Taylor, 1999), 49\% (Norman, Conner, \& Bell, 1999), or 45\% (Hagger, Chatzisarantis, \& Biddle, 2002), this explanation of predictability of intention by only three components of the theory of planned behaviour in this study is low. Responses to the ATIPDPE instrument have been influenced by the following: (a) internal variances within groups, by looking at three different base groups and then comparing between and within these, it was difficult to understand the effect of factors such as confidence, experience, and other such factors, which may have an impact upon participant responses and attitudes; (b) demographic data found that the majority of participants had not completed a university course relating to teaching students with disabilities between the undergraduate physical education students, only the postgraduate students had participated in this course, but the undergraduate physical education students had received information about this outside of university. It could then be suggested that the participants who had not been exposed to such information or experience may not have had the chance to fully comprehend and come to appropriate beliefs, subjective norm and perceived behavioural control relating to teaching students with physical disabilities in physical education; (c) the hypothetical nature of the ATIPDPE instrument may not evoke accurate decision making while completing the survey. This may therefore result in inaccurate responses, or responses that may be socially expected rather than true personal beliefs and attitudes. Recommendations for a future research may include further exploration of the differences among pre-service teachers, who have and have not completed a course relating to teaching students with disabilities as this may therefore provide further understanding about the impact of the course and hence provide teacher preparation institutions with valuable feedback as to the successfulness of the course and how to further improve it to target the development of positive attitudes and intentions of future teachers 
to ensure the implementation of successful inclusive programs throughout their career. This research was only conducted in one university in Italy, in order to achieve a stronger overall understanding of attitudes of pre-service teachers towards inclusion within Italy it would be necessary to complete similar research across a number of teacher preparation institutions throughout a variety of geographical locations and students across the country.

When considering the demographic data that was retrieved from this study, it is interesting that while $24.6 \%$ of postgraduate students expressed that they felt very competent to teach children with physical disabilities at the present time, when asked how competent they assume they will feel after graduation, $38.5 \%$ responded that they would feel somewhat or very competent, a positive improvement on the previous responses. When considering responses from first year undergraduate physical education students, their view about their competence to teach students with physical disabilities increased from the current time to after the graduation, with $32.8 \%, 34.4 \%$ expressing that they will feel very competent after graduation, and only $17.6 \%$ that they will feel not competent at all. While for the third year of undergraduate physical education students, their view about their competence today to teach students with physical disabilities only $13.3 \%$ feel very competent, with $27.6 \%$ expressing that they will feel very competent after graduation, and $22.4 \%$ that they will feel not competent at all.

These are disappointing results that suggest that the students will not feel competent and confident to implement inclusive programs at the start of their professional career, which places doubt upon the successfulness of such programs for students with and without disabilities.

\section{Conclusion}

Inclusion is an increasingly observed phenomenon throughout the world today. It is therefore necessary to have competent and confident teachers to implement successful programs ensuring that all students receive equal and adequate opportunities for developing and learning within a safe and encouraging environment. While overall attitudes of the first and third year undergraduate PE students and the second year postgraduate students from Faculty of Sport Sciences, University of Naples, Italy, are generally positive according to belief statement responses, the number of students who expressed that they do not feel competent at the present time and will not feel competent after graduation is worrying. As no significant differences among students who have and have not completed a university course relating to teaching students with disabilities was seen, it should therefore be a consideration for the teacher preparation institution to revise this course, as it seems that it did not have the desired effect of improving attitudes and intentions of the pre-service teachers towards teaching students with disabilities. As there may be only a short amount of time allocated to such a course, it is therefore necessary that the course would be effective by providing the students with information and experiences, which will improve their attitudes and intentions and hence their quality of teaching for all students.

\section{Acknowledgment}

The study was supported by the project "Support for creating excellent research teams and intersectoral mobility at Palacký University in Olomouc II" (CZ.1.07/2.3.00/30.0041).

\section{References}

Ajzen, I. (1991). The theory of planned behaviour. Organizational Behaviour and Human Decision Processes, 50, 179-211.

Ajzen, I. (2005). Attitudes, personality and behaviour (2nd ed.). Berkshire: Open University Press.

Avramidis, E., Bayliss, P., \& Burden, R. (2000). Student teachers' attitudes towards the inclusion of children with special educational needs in the ordinary school. Teaching and Teacher Education, 16, 277-293.

Banville, D., Desrosiers, P., \& Genet-Volet, Y. (2000). Translating questionnaires and inventories using a cross-cultural translation technique. Champaign, IL: Human Kinetics.

Block, M. E. (2000). A teacher's guide to including students with disabilities in general physical education (2nd ed.). Baltimore, MD: Paul H. Brookes.

Block, M. E., \& Vogler, E. W. (1994). Inclusion in regular physical education: The research base. Journal of Physical Education, Recreation, and Dance, 65, 40-44.

Breckler, S. J., \& Wiggins, E. C. (1992). On defining attitude and attitude theory: Once more with feeling. In A. R. Pratkanis, S. J. Breckler, \& A. C. Greenwald (Eds.), Attitude structure and function (pp. 407-427). Hillsdale, NJ: Erlbaum.

DePauw, K. P., \& Doll-Tepper, G. (2000). Toward progressive inclusion and acceptance: Myth or reality? The inclusion debate and bandwagon discourse. Adapted Physical Activity Quarterly, 17, 135-143.

Doulkeridou, A., Evaggelinou, C., \& Kudláček, M. (2010). Components of attitudes toward the inclusion of students with disabilities in physical education. Acta Universitatis Palackianae Olomucensis. Gymnica, 40(4), 63-68.

Downing, J. E., Morrison, A. P., \& Berecin-Rascon, M. A. (1996). Including elementary school students with autism 
and intellectual impairments in their typical classrooms: Process and outcomes. Developmental Disabilities Bulletin, 24, 20-45.

Falvey, M. A. (1995). Inclusive and heterogeneous schooling: Assessment, curriculum, and instruction. Baltimore, MD: Paul H. Brookes Publishing Company.

Folsom-Meek, S. L., Nearing, J. R., Groteluschen, W., \& Krampf, H. (1999). Effects of academic major, gender, and hands-on experience on the attitudes of preservice professionals. Adapted Physical Activity Quarterly, 16, 389-402.

Fournidou, I., Kudláček, M., \& Evagellinou, C. (2011). Attitudes of in service physical educators teachers toward teaching children with physical disabilities in general physical education in Cyprus. European Journal of Adapted Physical Activity, 4, 22-38.

Hagger, M. S., Chatzisarantis, N. L. D., \& Biddle, S. J. H. (2002). A meta-analytical review of the theories of reasoned action and planned behaviour in physical activity: Predictive validity and the contribution of additional variables. Journal of Sport \& Exercise Psychology, 24, 3-32.

Kudláček, M. (2001). An attitude toward inclusion instrument based on the theory of planned behaviours for prospective Czech physical educators (Unpublished doctoral dissertation). Texas Woman's University, Department of Kinesiology, Denton, TX.

Kudláček, M., Válková, H., Sherrill, C., Myers, B., \& French, R. (2002). An inclusion instrument based on planned behaviour theory for prospective physical educators. Adapted Physical Activity Quarterly, 19, 280-299.

Leyser, Y., Kapperman, G., \& Keller, R. (1994). Teacher attitudes towards mainstreaming: A cross-cultural study in six months. European Journal of Special Needs Education, 9, 1-15.

Lienert, C., Sherrill, C., \& Myers, B. (2001). Physical educator's concerns about integrating children with disabilities: A cross-cultural comparison. Adapted Physical Activity Quarterly, 18, 1-17.

Livi Bacci, M. (1999). Introduzione alla demografia [Introduction to demography]. Torino: Loescher editore.

McMurray, C. A. (2003). The use of inclusive opportunities to promote positive attitudes towards inclusion in physical activities (Unpublished Master's thesis). University of Stellenbosch, Faculty of Education, Stellenbosh, South Africa.
Meegan, S., \& MacPhail, A. (2006). Irish physical educators' attitude toward teaching students with special educational needs. European Physical Education Review, 12, 75-97.

Norman, P., Conner, M., \& Bell, R. (1999). The theory of planned behaviour and smoking cessation. Health Psychology, 18, 89-94.

Rizzo, T. L. (1993). Physical educators' attitude toward teaching individuals with disabilities-III. Unpublished survey. Department of Kinesiology, California State University, San Bernardino, CA.

Schmidt-Gotz, E., Doll-Tepper, G., \& Lienert, C. (1994). Attitudes of university students and teachers toward integrating students with disabilities in regular physical education classes. Physical Education Review, 17, 45-57.

Schnorr, R. F. (1990). "Peter? He comes and goes..." First graders perspectives on a part-time mainstream student. Journal of the Association for Persons with Severe Handicaps, 15, 231-240.

Sheeran, P., \& Taylor, S. (1999). Predicting intention to use condoms: A meta-analysis and comparison of the theories of reasoned action and planned behaviour. Journal of Applied Social Psychology, 29, 1624-1675.

Stainback, W., \& Stainback, S. (1992). Support networks for inclusive schooling: Interdependent integrated education. Baltimore, MD: Paul H. Brookes Publishing Co.

Taylor, A., Peterson, C. A., McMurray-Schwartz, P., \& Guillou, T. S. (2002). Social skills interventions: Not just for children with special needs. Young Exceptional Children, 5(4), 19-26.

Tripp, A., \& Rizzo, T. (2006). Disability labels affect physical educators. Adapted Physical Activity Quarterly, 23, 310-326.

Tripp, A. S., \& Sherrill, C. (1991). Attitude theories of relevance to adapted physical education. Adapted Physical Activity Quarterly, 8, 12-27.

Vaughn, S., Elbaum, B. E., Schumm, J. S., \& Hughes, M. T. (1998). Social outcomes for students with and without learning disabilities in inclusive classrooms. Journal of Learning Disabilities, 31, 428-436.

Zimbardo, P. G., \& Leippe, M. R. (1991). The psychology of attitude change and social influence. New York, NY: McGraw-Hill. 